Our Nature (2005)3:83-90

\title{
Wildlife Biodiversity in Bhawal National Park: Management Techniques and Drawbacks of Wildlife Management and Nature Conservation
}

\author{
D.S. Kabir and A.Z. Ahmed \\ Environmental Biology Laboratory, School of Environmental Science and Managemnt, Independent University, \\ Bangladesh Plot \# 14, Road \#14, Baridhara, Dhaka 1212, Bangladesh \\ Email:dshkabir@iub.edu.bd
}

\begin{abstract}
This paper emphasizes wildlife biodiversity and the management techniques and drawbacks particularly in Bhawal National Park. The park was declared a National Park in 1982; there was a great diversity of animal species at Bhawal National Park especially peafowl and jungle fowl dating back, to the British era as well as the Pakistani era. But unfortunately during and after 1971 there were neither reports nor any sighting of these attractive creatures. It is also remarkable; the remaining creatures such as civet, skunk, mongoose etc are endangered as well.

The park management techniques and how they can be improved in order to preserve wildlife from the viewpoint of the Forest Department as the villagers couldn't give any. Information through field observations, interviews and focus group discussions were collected. Conservation is the only alternative measure remaining for the rapidly dwindling small area of the Sal forest; The WMNCC will definitely have to come into effect if a consensus and status of the existing wildlife is to be published; The park management staff can also put up some colorful signboards depicting what species of wildlife that the tourist can find; Co-management of protected areas has great importance for conservation.
\end{abstract}

Key words: Bhawal National Park, Management technique, Nature conservation, Wildlife biodiversity

\section{Introduction}

Sal forests constitute a unique biological diversity, covering vast areas in the centre and east of Bangladesh. They constitute 70$75 \%$ "Sal" trees (Shorea robusta) including several other valuable trees and herbaceous species like the sun grass. Nevertheless, the Asian Development Bank (ADB) has actively promoted the destruction of the "Sal" forests by considering them of low productivity. In this regard, financing projects were granted for tree monoculture plantations using Eucalyptus and rubber among other species. Nowadays, the only big patch of Sal forest standing is that of Madhupur. Most of the forestland has been denuded, degraded and

occupied by forestry companies or displaced people (Gain, 1998). Contribution on forest management (Bourgecis, 2003), resident people and protected area (Calhaun, 1991), natural resource management (Michel and Gayton, 2002), and structure and diversity of natural and managed Sal forest in the Terai of Nepal (Webb and Ram, 2003) have also focus on the wildlife biodiversity.

The wildlife at Bhawal National Park was well known for its peacocks, tiger, leopard (black panther also) elephant, clouded leopard, sambar deer, etc. However, the overall situation is that these wild lives have disappeared and few mammals (squirrel, 
D.S. Kabir and A.Z. Ahmed / Our Nature (2005)3:83-90

mongoose, jackal, civet, jungle cat, etc.), few reptiles (monitor lizard, snakes) and some indigenous birds remain (Sarker and Fazlul Huq, 1985). Another corresponding survey has identified a total 64 animal species (10 amphibians, 9 reptiles, 39 birds and mammals).

The objectives of the study were to record and assess the present situation of animal species such as, the amphibians, reptiles, birds and mammals; to identify the constraints and contentment; and to study the park management techniques and make some recommendations on how to improve it, in order to preserve of what's left.

\section{Study area:}

The study area lies in Dhaka Forest Division, about $40 \mathrm{~km}$ north of the capital city Dhaka, from where it is easily accessible throughout the year by road. It has been kept under IUCN management category as a protected landscape.

This Bhawal National park $\left(24^{\circ} 01^{\prime} \mathrm{N}\right.$, $90^{\circ} 20^{\prime} \mathrm{E}$ ), Gazipur was established and maintained as a national park in 1974 but not declared officially until 1982 under the Bangladesh Wildlife Act, 1974. This national park covers 5,000 ha but sometimes for development works, it extends to the middle of the park's core area of 940 ha. The present feature of the forest area is actually honeycombed with habitations and rice fields. The topography is characterized by low hills, which rise $3.0-4.5 \mathrm{~m}$ above the surrounding paddy fields locally known as 'chalas' are intersected by numerous depressions or baids.

The dominant forest trees Sal Shorea robusta of the national park have been almost completely removed, but now protection program has planted sal which covers $90 \%$ of the area (Womersley, 1979; Sarker and Fazlul Huq, 1985). Recently, 221 species of plants
(24 species climber, 27 species grass, 3 species palm, 105 species herb, 19 species shrubs and 43 species tree) have been recorded. Among trees, Ajuli Dillenia pentagyna, kumbhi Careya arborea, Terminalia belerica, Gandhi gajari Miliusa velutura, etc. are commonly found in the national park. The undergrowth vegetations include Melostoma, Lantala, moinakata Randia dumetorum, etc. This national park is inhabitated by a few mammals such as Vulpes bengalensis, jackal Canis aureus, small Indian civet Viverricula indica, wild boar Sus scrofa, etc. The avifauna is similar to that found in Madhupur National Park (Sarker and Fazlul Huq, 1985). Recreational and educational facilities have been improved in the beginning under the management of the Forest Development (FD) but plans were gradually discontinued and operations became limited to reforestation of damaged areas (Oliver, 1979; Womersley, 1979; Sarker and Fazlul Huq, 1985). Because of removal of original forest vegetation, depletion of wildlife from this park has taken place now.

\section{Materials and Methods}

The materials used for conservation were information from primary sources such as interviews and also from books and journals. The method that was applied was spotting, identifying and recording the wildlife that came across and finally using the IUCN Red Book of threatened birds, mammals, reptiles and amphibians to check the status of the wildlife; had come across as for information obtained from the villagers and FD officials focus group discussions and a one-on-one Q\&A discussion method was applied respectively. In total, 13 people were interviewed among which 10 people were villagers and 3 were FD officials. 


\section{Focus group discussion}

In focus group discussion, the elder men were asked about wildlife with regards to British, Pakistani and Present day (after1971), what types of wildlife such as birds, mammals, reptiles and amphibians exist here, what were the reasons they thought were responsible for wildlife deterioration, did they agree with the FD's management techniques. On the status of the wildlife of the past, they being elderly men told the names one by one as for the number of wildlife that exist today they gave only guessed numbers, as for wildlife deterioration, they strongly accused the FD.

\section{One-on-one $Q$ and $A$ discussion}

In one-on one Q\&A discussion the two ACFs as well as the forest ranger was asked about the wildlife management techniques, their success rates, the drawbacks of management particularly the Wildlife Management and Nature Conservation Circle that only exists nominally and the problems with the villagers in not wanting to give up land to the FD.

\section{Results}

From the discussion with the villagers especially the elderly men, the information regarding wildlife species, number and habitat from the British period to the present day are given below in their own version. In the British time habitats were dense forest cover as well as dense underground growth for peacock (1000), Panthera spp. $>100$, deer $>100$ or so, pangolins 50 or so $>500$, raptors $>50$, bears 100 , innumerable, leopard, elephant, clouded leopard, gaur etc. Similarly, before 1971 in Pakistan period, there still existed peafowl, jungle fowl, wild boar, barking deer, clouded leopard, leopard, etc. in the same habitat like that of British period but environment was being worse than what it was in the past. In Bangladesh period (after 1971), the population of mammals have decreased remarkably, however, birds population show constancy in the dwindling habitats. The birds, reptiles and mammals recorded during the survey are listed in the tables 1-3 and the reasons for depletion of animals in the tables 4-7.

\section{Discussion}

From the FGD that took place the information regarding the time line analysis the mammalian fauna was very rich during the British period. The tiger and the leopard were very numerous then and at times preyed on the livestock of the local villagers as well as instilling fear inside them and at times the villagers would come across a cattle carcass. As for the other mammalian species there was nothing significant about them though the sambar deer was remarkably attractive for its antlers. Among the avifauna, the most notable birds were the peacock and the jungle fowl. The peacock was numerous which was why Bhawal National Park was often called Peacock Park. The jungle fowl was a smart creature detecting the presence of humans and took off before they could arrive there to catch them and in order to catch them domestic chicken would be used as bait to attract them.

In the Pakistani period the leopard and the tiger dwindled and a few of the big cats, etc remained but the real loss in wildlife biodiversity took place during the war from that situation arose the present situation that can be seen on Table 1 .

From the discussion regarding frogs, the most common ones were the Indian bullfrog, Common Indian tree frog, Cricket frog and the common asian toad (Tables 3A, 3B and $3 \mathrm{C})$. About reptiles, the Bengal monitor, the pythons, the kraits, cobras and keelbacks are the most common. 
D.S. Kabir and A.Z. Ahmed / Our Nature (2005)3:83-90

Figure 1. Abundance of 10 most dominant birds during the study periods

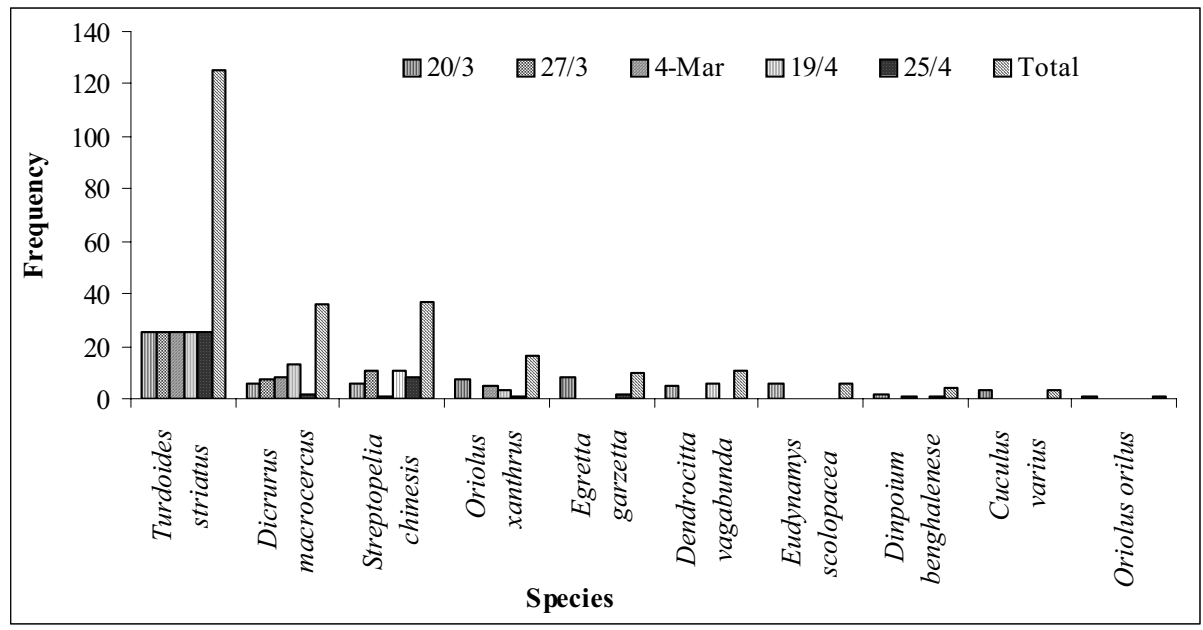

Table 1. Time line analysis

\begin{tabular}{|l|l|l|l|}
\hline Period & \multicolumn{1}{|c|}{ Pre-existing wildlife } & \multicolumn{1}{|c|}{ Number of species } & \multicolumn{1}{c|}{ Habitat } \\
\hline British era & $\begin{array}{l}\text { Peacocks, tiger, leopard } \\
\text { (Black panther also) } \\
\text { elephant, clouded leopard, } \\
\begin{array}{l}\text { Himalayan black bear, } \\
\text { barking deer, gaur, etc }\end{array}\end{array}$ & $\begin{array}{l}\text { Peacocks: about 1,000 (say) } \\
\text { Pantheridae species: } \\
\text { Deer: }>100 \text { or so } \\
\text { Pangolins: } 50 \text { or so: }>500 \\
\text { Raptors: }>50 \\
\text { Bears: } 100 \\
\text { Birds: innumerable (in thousands) }\end{array}$ & $\begin{array}{l}\text { Dense forest cover as } \\
\text { well as dense under } \\
\text { growth for most species } \\
\text { that have been mentioned } \\
\text { here }\end{array}$ \\
\hline Pakistani & $\begin{array}{l}\text { Peafowl, jungle fowl, Wild } \\
\text { boar, barking deer, clouded } \\
\text { leopard, leopard, etc }\end{array}$ & $\begin{array}{l}\text { Peacocks and other birds: about 500 } \\
\text { or more (say) } \\
\text { Barking deer: } 100 \text { or so } \\
\text { Cats: around } 100\end{array}$ & $\begin{array}{l}\text { Dense forest but } \\
\text { somewhat less than } \\
\text { compared to what it was } \\
\text { in the past. }\end{array}$ \\
\hline $\begin{array}{l}\text { Bangladesh } \\
\text { After } \\
1971)\end{array}$ & $\begin{array}{l}\text { Fox, jackal, small Indian } \\
\text { civet, fishing cat, etc and } \\
\text { birds such as Jungle Babbler, } \\
\text { etc }\end{array}$ & $\begin{array}{l}\text { Mammals: } 100 \text { or so } \\
\text { Birds: innumerable } \\
\text { Dense undergrowths and } \\
\text { covers of what ever } \\
\text { remains }\end{array}$ \\
\hline
\end{tabular}

Table 2. Name of birds that were spotted in the study spots along with their names and numbers.

\begin{tabular}{|c|c|c|c|c|c|c|c|c|}
\hline \multirow[b]{2}{*}{ English name } & \multirow[b]{2}{*}{ Scientific name } & \multirow[b]{2}{*}{ Family name } & \multicolumn{5}{|c|}{ Frequency } & \multirow[b]{2}{*}{ 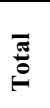 } \\
\hline & & & \begin{tabular}{|r|}
$2004 /$ \\
$3 / 20$
\end{tabular} & \begin{tabular}{|r|}
$2004 /$ \\
$3 / 27$
\end{tabular} & \begin{tabular}{|r|}
$2004 /$ \\
$4 / 03$
\end{tabular} & \begin{tabular}{|r|}
$2004 /$ \\
$4 / 19$ \\
\end{tabular} & \begin{tabular}{|r|}
$2004 /$ \\
$4 / 25$
\end{tabular} & \\
\hline Jungle babbler & Turdoides striatus & Sylvidae & 25 & 25 & 25 & 25 & 25 & 125 \\
\hline Black-headed oriole & Oriolus xanthrus & Oriolidae & 7 & - & 5 & 3 & 1 & 16 \\
\hline Black drongo & Dicrurus macrocercus & Dicuridae & 6 & 7 & 8 & 13 & 2 & 36 \\
\hline Spotted dove & Streptopelia chinesis & Columbidae & 6 & 11 & 1 & 11 & 8 & 37 \\
\hline Asian Koel & Eudynamys scolopacea & Cuclidae & 6 & - & - & - & - & 6 \\
\hline
\end{tabular}


D.S. Kabir and A.Z. Ahmed / Our Nature (2005)3:83-90

\begin{tabular}{|c|c|c|c|c|c|c|c|c|}
\hline Little egret & Egretta garzetta & Ardeidae & 8 & - & - & - & 2 & 10 \\
\hline Golden oriole & Oriolus orilus & Oriolidae & 1 & - & - & - & - & 1 \\
\hline Indian treepie & Dendrocitta vagabunda & Corvidae & 5 & - & - & 6 & - & 11 \\
\hline $\begin{array}{l}\text { Common Hawk } \\
\text { Cuckoo (Brainfever } \\
\text { bird) }\end{array}$ & Cuculus varius & Cuclidae & 3 & - & - & - & - & 3 \\
\hline $\begin{array}{l}\text { Lesser Golden-backed } \\
\text { woodpecker }\end{array}$ & Dinpoium benghalenese & Picidae & 2 & - & 1 & - & 1 & 4 \\
\hline Brahminy kite & Haliastur Indus & Accippitridae & 2 & 2 & 1 & 1 & 2 & 8 \\
\hline Black kite (Pariah kite) & Milvus migrans & Accippitridae & 2 & 2 & 1 & 2 & 2 & 9 \\
\hline Red-vented bulbul & Pycnonotus cafer & Pycnonotidae & 1 & - & - & - & - & 1 \\
\hline Rose-ringed parakeet & Psitticula-ta krameri & Psitticidae & 1 & 3 & - & - & - & 4 \\
\hline Stone chat & Saxicola torquata & Muscicapidae & 1 & 9 & 5 & 25 & - & 40 \\
\hline Common myna & Acrido therestis & Sturnidae & - & 1 & 5 & - & - & 6 \\
\hline Red-whiskered bulbul & Pycnonotus jacosus & Pycnonotidae & - & 5 & - & - & - & 5 \\
\hline Jungle crow & Corvus macrorhynchos & Corvidae & - & 1 & 8 & - & - & 9 \\
\hline Small blue kingfisher & Alcedo atthis & Alcedinidae & - & - & 10 & 1 & - & 11 \\
\hline Oriental magpie robin & Copysychus saularis & Muscicapidae & - & - & 1 & - & - & 1 \\
\hline Blue rock pigeon & Columbia livia & Columbidae & - & - & 1 & - & 1 & 2 \\
\hline Indian pond heron & Ardeola grayii & Ardeidae & - & - & - & - & - & \\
\hline Orange-headed thrush & Zoothera citrina & Muscicapidae & - & - & - & 1 & 13 & 14 \\
\hline $\begin{array}{l}\text { Little scaly-bellied } \\
\text { green woodpecker }\end{array}$ & Picus xanthopygaeus & Picidae & - & - & - & 1 & - & 1 \\
\hline Large cuckoo-shrike & Corcina macei & Corvidae & - & - & - & 1 & - & 1 \\
\hline Rufous-backed shrike & Lanis schach & Corvidae & - & - & - & 1 & 1 & 2 \\
\hline Common Hoopoe & Uрора Eрорs & Upipidae & - & - & - & 2 & - & 2 \\
\hline Asian pied starling & Sturnus contra & Sturnidae & - & - & - & 1 & - & 1 \\
\hline Common iora & Aegithina tiphia & Corvidae & - & - & - & - & 2 & 2 \\
\hline \multicolumn{3}{|c|}{ Total birds ( 29 species) and individuals } & 76 & 66 & 72 & 94 & 60 & 368 \\
\hline
\end{tabular}

Table 3. Amphibians, Reptiles and Mammals

\begin{tabular}{|c|c|c|}
\hline Name of interviewee & Habitat & Number and type of species \\
\hline \multicolumn{3}{|l|}{ Amphibians } \\
\hline Sudhanya Burman & Lakes and ponds & $\begin{array}{l}\text { Indian Bullfrog Hoplobactrachus tigerinus } \\
\text { Estimated number: } 100 \text { or greater }\end{array}$ \\
\hline Abdur Rashid & Trees close to a water body & $\begin{array}{l}\text { Common Indian tree frog Polypedetaes } \\
\text { maculatus Estimated number: }>100\end{array}$ \\
\hline Mahendra Burman & $\begin{array}{l}\text { Ponds but sometimes can be found in } \\
\text { small puddles }\end{array}$ & $\begin{array}{l}\text { Cricket frog Limnonectus limnocharis Estimated } \\
\text { number: }>100\end{array}$ \\
\hline Raj Kumar & \multirow{2}{*}{ Same as that of the cricket frog } & \multirow{2}{*}{$\begin{array}{l}\text { Common Asian Toad Bufo melanosticus } \\
\text { Estimated number: }>100\end{array}$} \\
\hline Md.Kumuruddin & & \\
\hline \multicolumn{3}{|l|}{ Reptiles } \\
\hline \multirow{3}{*}{$\begin{array}{l}\text { Sudhanya Burman } \\
\text { Abdur Rashid } \\
\text { Mahendra Burman } \\
\text { Raj Kumar } \\
\text { Md.Kumuruddin }\end{array}$} & $\begin{array}{l}\text { Under ground habitats some like the } \\
\text { prefer the water }\end{array}$ & $\begin{array}{l}\text { Bengal Monitor Varanus bengalensis } \\
\text { Estimated number: } 100\end{array}$ \\
\hline & & $\begin{array}{l}\text { Rock Python Python molurus } \\
\text { Estimated number: } 50 \text { or so }\end{array}$ \\
\hline & & $\begin{array}{l}\text { Checkered Keelback Xenochrophis piscator } \\
\text { Estimated number: } 100\end{array}$ \\
\hline
\end{tabular}


D.S. Kabir and A.Z. Ahmed / Our Nature (2005)3:83-90

\begin{tabular}{|l|l|l|}
\hline \multirow{5}{*}{} & & $\begin{array}{l}\text { Reticulated Python Python reticulata } \\
\text { Estimated number: 50 }\end{array}$ \\
\cline { 3 - 3 } & & $\begin{array}{l}\text { Bengal cobra Naja kouthia } \\
\text { Estimated number: } 50\end{array}$ \\
\hline Mammals & & \\
\hline Name of interviewee & Habitat & Number and type of species \\
\hline \multirow{4}{*}{$\begin{array}{l}\text { Sudhanya Burman } \\
\text { Abdur Rashid } \\
\text { Mahendra Burman } \\
\text { Raj Kumar } \\
\text { Md.Kumuruddin }\end{array}$} & Forests, village and towns & $\begin{array}{l}\text { Rhesus macaque } \text { Macaca mulatta } \\
\text { Estimated number: }>200\end{array}$ \\
\cline { 2 - 3 } & $\begin{array}{l}\text { Sal Shorea robusta in association with } \\
\text { Dillenia pentagnya, etc. }\end{array}$ & $\begin{array}{l}\text { Irrawaddy squirrel Collasciurus pygerythrus } \\
\text { Estimated number: }>200\end{array}$ \\
\cline { 2 - 3 } & Any kind of environment such as & $\begin{array}{l}\text { Jackal Canis aureus } \\
\text { Estimated number: }>100\end{array}$ \\
\cline { 2 - 3 } & villages & $\begin{array}{l}\text { Bengal fox Vulpes bengalensis } \\
\text { Estimated number: }>100\end{array}$ \\
\cline { 2 - 3 } & Open lands, scrubs and cultivation & $\begin{array}{l}\text { Common Mongoose Herpestes edwardsii } \\
\text { Estimated number: }>100\end{array}$ \\
\cline { 2 - 3 } & Woods, bushes and scrubs & $\begin{array}{l}\text { Small Indian civet } \text { Viverricula indica } \\
\text { Estimated number: }>100\end{array}$ \\
\cline { 2 - 3 } & $\begin{array}{l}\text { Long grass or scrubs to live in, } \\
\text { shelters under holes or under rocks }\end{array}$ & \\
\hline
\end{tabular}

Table 4: Reasons or factors responsible for wildlife deterioration

\begin{tabular}{|l|l|l|}
\hline Name of interviewee & The reasons for wildlife deterioration & Response \\
\hline 1 Sudhanya Burman & $\begin{array}{l}\text { 1 Corruption on the part of the wildlife officials } \\
\text { 2 Illegal logging of trees } \\
\text { 3 Encroachment of the forest by the farmers } \\
\text { 4 Poaching of animals } \\
5 \text { All of the above }\end{array}$ & Reasons 1 and 2 \\
\hline 2 Abdur Rashid & Do & $\begin{array}{l}\text { Same as that of the first } \\
\text { interviewee }\end{array}$ \\
\hline 3 Mahendra Burman & Do & Same reason \\
\hline 4 Raj Kumar & Do & Reason 3 \\
\hline 5 Md. Kumuruddin & Do & Reason 3 \\
\hline
\end{tabular}

Table 5. Wildlife management techniques applied in the national park

\begin{tabular}{|l|l|}
\hline Techniques & Success rate \\
\hline 1 No electronic equipments allowed & $95 \%$ \\
\hline 2 Nesting, roosting and food for birds & $>90 \%$ \\
\hline 3 No hunting & almost $100 \%$ \\
\hline
\end{tabular}

Table 6. Problems associated with management of wildlife from the forest officials' viewpoint

\begin{tabular}{|l|l|}
\hline Problem 1 & Beat controlled by Rajendrapur range \\
\hline Problem 2 & Not a 100 percent Reserve forest \\
\hline Problem 3 & 52 families still residing in the 400 acres of forest land \\
\hline Problem 4 & No survey nor any consensus was carried out regarding information of mammals and reptiles \\
\hline Problem 5 & DFO carrying out both functions regarding Forest Department as well as that of WMNCC \\
\hline Problem 6 & No independent DFO as well as no jurisdiction under the present DFO \\
\hline
\end{tabular}

Table 7. Problems with people of Bonogram (Kuichamara) village and the FD

\begin{tabular}{|l|l|l|}
\hline Problem 1 & Reluctant to give up land \\
\hline Problem 2 & Wants a new bridge to be bu
\end{tabular}

\begin{tabular}{|l|l} 
Problem 2 & Wants a new bridge to be build up and a new road to be build up for ease of travel
\end{tabular}

\begin{tabular}{|l|l}
\hline Problem 3 & Considers FD to be the bigger thieves
\end{tabular} 
As for mammals, the monkey they say is very troublesome during the paddy-collecting season along with the wild boar and barking deer can be seen coming out from the army cantonment where the wildlife roams freely and undisturbed.

The first 3 people said reasons 1 and 2 as because they are inter-connected and also they had personal grudges. The last two people said reason 3 as well as only the presence of sal trees, which cannot forever sustain birds and primates.

From the Q\&A that with the forest officials regarding wildlife management techniques (Table5), the success rate for not allowing electronic equipments was $95 \%$ because there are still a few people who secretly bring their stereos in the park that resulted in violent altercations with the FD staff resulting in few people coming in the park nowadays and little revenue coming in. Bird accommodation sites such as nesting, roosting and feeding that have been set up that has yielded more than $90 \%$ results as a result of the success of the first technique. No hunting and illegal felling is almost $100 \%$ as there are guards checking the 942 hectares of forest round the clock only a few birds getting shot and only the monkey and the wild boar are driven away during the paddy season.

About problems associated with management of wildlife from the forest officials' viewpoint, the first problem is that trees that are planted by the Bhawal National Park are grown and cared for in the Rajendrapur range meaning that the ACFs have the dual responsibility that in future could lead to clashes regarding administration of the trees. Then second problem is that in order to have complete control of the forest it has to be 100 $\%$ Reserved Forest (RF) and in order to be an $\mathrm{RF}$ there are 52 families residing in 400 acres of the forest land that have to give their land to the FD which is the third problem and is in fact connected to the second problem. The fourth, fifth and sixth problems are more connected to each other than the second and the third since the DFO of the FD is also the DFO of the Wildlife Management and Nature Conservation Circle (WMNCC) and WNMCC happens to be a revived name of the previously known Wildlife Circle that was established in 1976 but abolished in 1983allgedly in the interests of the economy and following the Inam Commission, it only exists in paper and pen and till-to-date there is no jurisdiction under the present DFO, as it has not yet come from the government also the ACF and DFO are synonymously called the FD ACF and DFO as well as the WMNCC ACF and DFO though in the case of the latter the term exists nominally. The ACF stressed out that an independent DFO along with the government jurisdiction is a must if the WMNCC is to take effect to obtain the consensus and status of the mammals as well as reptiles and amphibians, which in the case of Khulna and Chittagong has been successful.

As well as problems with the people of Bonogram (Kuichamara) village, the local villagers are reluctant to give up their land claiming it to be the land of their forefathers saying what the FD do with more land as they already have 940 hectares of land besides the FD would not have any agricultural output. They consider FD to be bigger thieves in the sense that 4,000 spp. of trees such as mangium, acacia and shegun are gone and in their place only 10,000 acacia trees are there planted a few years ago on the high land also fruit trees dating back to the Raja of Bhawal have totally disappeared and 5lakhs of older trees have disappeared whenever a big occasion takes place like the opening of 


\section{D.S. Kabir and A.Z. Ahmed / Our Nature (2005)3:83-90}

market. Therefore if any outsider cuts a tree or a branch, it is nothing compared to what the FD does. The people want a new bridge to be built up to make it easier for them to move from one union to another as well as for the school children they also want a new road to be built to facilitate their movements such as going to markets, so that the picnickers can park their own vehicles.

The only positive thing they had said was they found the forest management techniques suitable to them because what is good for the forest is good for them and no mention of management techniques from their side only for a wall to be built starting from the picnic spot \#10 to Kapashia main road.

These are the discussions regarding the tables and figure of the ten most dominants bird species.

\section{Conclusions}

Conservation is the only alternative measure remained for the rapidly dwindling small area of the Sal forest. Enforcement of the laws, forestry extension in the adjacent areas, motivation and campaign among the people can stop further depletion of the forest.

The WMNCC will have to come into effect if a consensus and status of reptiles, amphibians and mammals that exist in the park is to be published and the government should as soon as possible give the jurisdiction to an independent DFO.

The park management authority can put up some colorful signboards depicting what species of birds, mammals, reptiles and amphibians presently existing that the tourist can find whenever he arrives there. A website can be developed so that information can be available at the net regarding the status of Sal forests with regards and its resident wildlife to the interested persons.

Co-management of protected areas has great importance for conservation, although provision of benefits and compensation for lost access remain major issues.

\section{References}

Bourgeois, W.W. 2003. Future forest management in British Columbia: A proposed vision, goals and forest management framework. British Columbia Journal of Ecosystems and Management 4(1): art 2.

Calhoun, B.J. 1991. Plight of the Ik. In: Resident Peoples and Protected Areas: Social Dilemmas and Strategies in International Conservation, (Eds. C.W. Pattrick and R.B. Steven). Tucson: University of Arizona Press. pp. 55-60

Gain, P. 1998. The last forests of Bangladesh. Society for Environment and Human Development (SEHD).

Michel, H. and D. Gayton 2002. Linking Indigenous peoples' knowledge and western science in natural resource management: A dialogue. British Columbia Journal of Ecosystems and Management 2(2): art 3 .

Olivier, R.C.D. 1979. Wildlife conservation and management in Bangladesh. UNDP/FAO Project $\mathrm{BGD} / 72 / 005$. FAO, Forest Research Institute, Chittagong. 121p.

Sarker, N.M. and A.K.M. Fazlul Huq 1985. Country report on national parks, wildlife sanctuaries and game reserves of Bangladesh. Prepared for the 25th Working Session of IUCN's Commission on National Parks and Protected Areas. Corbett National Park, India. 5p.

Webb, E.L. and N. Ram 2003. Structure and diversity of natural and managed sal (Shorea robusta Gaerten. f.) forest in the Terai of Nepal. Journal of Forestry 176(1-3): 337-353.

Womersley, J.S. 1979. Botanic Garden Dacca, commercial horticultural forest botany and national parks. UNDP/FAO Project BGD/72/005 FAO, Forest Research Institute, Chittagong. 71p. 